\title{
Hydrological and Hydrochemical Characteristics of the Iron-Manganese Meromictic Freshwater Lake Svetloe (Arkhangelsk Region)
}

\author{
Natalia M. Kokryatskaya*, Artem V. Chupakov, \\ Kseniya V. Titova, Anna A. Chupakova, Svetlana A. Zabelina, \\ Olga Yu. Moreva, Natalia V. Neverova and Tatyana A. Zhibareva \\ N. Laverov Federal Center for Integrated Arctic Research RAS \\ 23 Severnoi Dviny Emb., Arkhangelsk, 163000, Russia
}

Received 12.01.2017, received in revised form 07.07.2017, accepted 26.10.2017, published online 01.02.2018

Meromictic lakes are a unique model for the study of the anaerobic processes of organic matter degradation, such as methanogenesis and sulphate reduction. As a result of activity of sulfate-reducing bacteria hydrogen sulfide accumulates in monimolimnion of these lakes, whereas chemocline is the area of sharp vertical gradients of physical and chemical conditions and as a consequence is the ecological niche for different planktonic microorganisms. This paper describes some characteristics of meromictic freshwater Lake Svetloe, located in the north of the Arkhangelsk region, for which ironmanganese type of meromixia was defined. The distribution of the studied parameters corresponds to the distribution of the specific for meromictic lakes water layers formed in the presence of stable stratification. In the transition layer (chemocline) a sharp decrease in the oxygen content (almost to the analytical zero) is accompanied by an equally sharp increase in the value of the water conductivity and the emergence of dissolved hydrogen sulfide in the water. In the anaerobic zone the conductivity values remain high and accumulation of nutrients, iron, manganese, and hydrogen sulphide (average $30 \mathrm{mg} / \mathrm{l}$ ) occurs. Besides, the significant decrease in the content of dissolved sulphate caused by its consumption by sulfate-reducing bacteria was noted in this layer. The number of sulphate-reducing bacteria in the water column during the time of observation varied in the range of $10-10^{6} \mathrm{cells} / \mathrm{ml}$ with the highest content in the chemocline zone, where the maximum amounts of hydrogen sulphide (up to $130 \mathrm{mg} / \mathrm{l})$ were also found.

Keywords: Arkhangelsk region, meromictic lake, chemical stratification, nutrients, sulfate reduction, sulfate-reducing bacteria.

Citation: Kokryatskaya N.M., Chupakov A.V., Titova K.V., Chupakova A.A., Zabelina S.A., Moreva O.Yu., Neverova N.V., Zhibareva T.A. Hydrological and hydrochemical characteristics of the iron-manganese meromictic freshwater lake Svetloe (Arkhangelsk Region). J. Sib. Fed. Univ. Biol., 2019, 12(2), 147-159. DOI: 10.17516/1997-1389-0036.

(C) Siberian Federal University. All rights reserved

* Corresponding author E-mail address: nkokr@yandex.ru 


\title{
Гидролого-гидрохимические характеристики \\ меромиктического железо-марганцевого пресноводного озера Светлое (Архангельская область)
}

\author{
Н.М. Кокрятская, А.В. Чупаков, \\ К.В. Титова, А.А. Чупакова, С.А. Забелина, \\ О.Ю. Морева, Н.В. Неверова, Т.А. Жибарева \\ Федеральный исследовательский центр \\ комплексного изучения Арктики \\ им. академика Н.П. Лаверова РАН \\ Россия, 163000, Архангельск, наб. Северной Двиньл, 23
}

Меромиктические водоемы - уникальная модель для изучения анаэробных процессов деструкции органического вещества, одним из которых (наряду с метаногенезом) является сульфатредукция. В результате деятельности сульфатредуциирующих бактерий в монимолимнионе этих водоемов накапливается сероводород, а в зоне хемоклина наблюдаются резкие вертикальные градиенты физико-химических условий и как следствие - развитие разнообразных микробных сообществ. В настоящей работе рассмотрены некоторые основные характеристики водной толщи меромиктического пресноводного озера Светлое, расположенного на севере Архангельской области, для которого достоверно установлен железо-марганцевый тип меромиксии. Наличие устойчивой стратификации с выделением характерных для меромиктических водоемов слоев нашло отражение в распределении изучаемых параметров. Так, в переходном слое (хемоклин) начало анаэробной зонь сопровождается резким увеличением величинь электропроводности и появлением в воде растворенного сероводорода. В нижележащцих горизонтах, где сохраняются достигнутые максимальные значения электропроводности, происходит накопление биогенных элементов, железа, марганца и сероводорода (в среднем 30 мкг/л); отмечено заметное снижение содержания растворенного сульфата, обусловленное его потреблением сульфатредуцирующции бактериями при генерации сероводорода. Численность сульфатредуцчирующих бактерий в водной толще за все время наблюдений колебалась в интервале от 10 до $10^{6}$ кл/мл, с максимумом содержания в зоне хемоклина, где также отмечены максимальные количества сероводорода (до 130 мкг/л).

Ключевые слова: Архангельская область, меромиктическое озеро, химическая стратификация, биогенные элементы, сульфатредукиия, сульфатредуциирующие бактерии.

\section{Введение}

Арктический бассейн является важнейшим звеном глобального кругооборота вещества и формирования климата Земли. Актуальность исследования процессов, про- мата. текающих в водоемах Субарктического и Арктического регионов России, определяется, прежде всего, нестабильностью их экологического состояния в условиях изменения кли$8-$ 
Формирование основных черт водного объекта происходит в результате суммарного действия климатического, ландшафтного, литологического и, при наличии, антропогенного факторов, а также внутриводоемных процессов. Большое число малых озер на обширной территории России, включающей различные климатические зоны, формы рельефа и геологические особенности, дает возможность изучать водные экосистемы при различных вариациях величины и направления результирующего вектора действия данных факторов. Отсутствие водообмена между поверхностными (миксолимнион) и придонными горизонтами приводит к образованию слоя «скачка» (хемоклина), где наблюдаются резкие градиенты гидрохимических условий, и статичной анаэробной зоны (монимолимнион). Подобные условия делают меромиктические водоемы уникальными объектами для изучения геохимии и микробиологии анаэробных процессов.

В настоящей работе рассмотрены некоторые основные характеристики водной толщи меромиктического пресноводного озера Светлое, для которого в ходе регулярных наблюдений, начатых в декабре 2009 г., достоверно установлен меромиктический статус с железо-марганцевым типом меромиксии (Кокрятская и др., 2011; Чупаков и др., 2013). Рассмотрено вертикальное распределение гидролого-гидрохимических характеристик водной толщи водоема, содержание некоторых основных ионов и растворенного углерода, биогенных элементов, сероводорода и численности сульфатредуцирующих бактерий.

\section{Материалы и методы}

Краткая характеристика района

и объекта исследования

Озеро Светлое находится в Приморском районе Архангельской области на расстоянии
63 км на северо-восток от г. Архангельска. Оно является первым в системе из пяти озер, дающих начало реке Светлой (водосборный бассейн Белого моря). Озерная котловина сформирована двумя ямами, между которыми находится мелководный перешеек с глубиной до 5 м, где располагается остров (рис. 1).

В восточной оконечности озера вытекает ручей шириной $\approx 1.5$ м и глубиной $\approx 0.3$ м, соединяющий его со следующим озером. В период интенсивного весеннего снеготаяния в мае 2012 г. был виден впадающий в западной оконечности озера ручей. В остальные периоды наблюдений видимого притока в озеро не обнаружено: это дает возможность предположить, что основное питание происходит за счет атмосферных осадков, паводковых и подземных вод (пресных кондиционных) (Малов, 2003). Рассчитанное приблизительное время пребывания воды в озере составило $\approx 321$ сут.

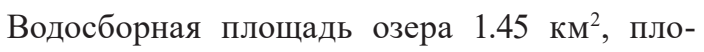
щадь акватории (без острова) 0.146 км² $^{2}$ объем 0.00176 км$^{3}$, максимальная глубина 39 м, средняя глубина 12 м. Большой вклад грунтовых вод в питание озера и малая заболоченность водосбора (0.4 \%) обуславливают высокую прозрачность вод (11 \pm 1 м) (Chupakov et al., 2017). Преобладающие на водосборной площади озер почвы представлены песчаными и подзолистыми на карбонатных отложениях.

\section{Методы исследования}

Материалом для данной работы послужили натурные наблюдения на озере Светлое, проведенные сотрудниками лабораторий пресноводных и морских экосистем и экоаналитических исследований ФГБУН ФИЦКИА РАН, за более чем пятилетий период. Интервал проведения работ в первые три года исследований составлял 1 месяц.

Отбор проб воды осуществлялся горизонтальным поликарбонатным непрозрач- 


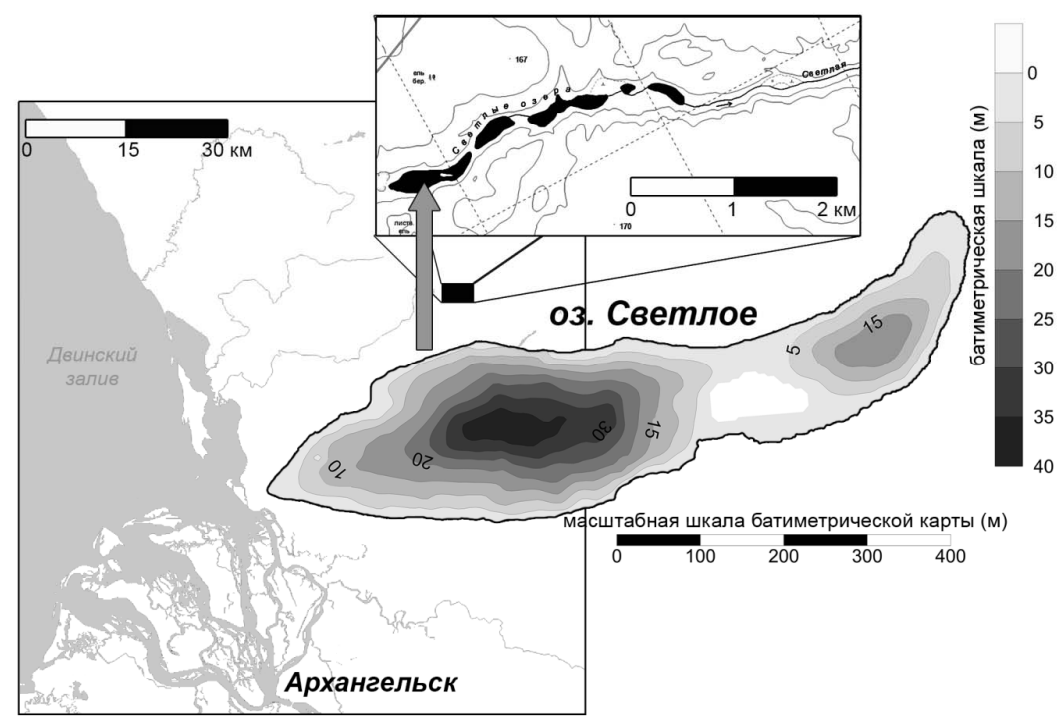

Рис. 1. Карта-схема расположения озера Светлое

Fig. 1. Schematic map of the Lake Svetloye location

ным батометром Aquatic Research со льда или с лодки ПВХ. Определение температуры водной толщи и концентрации кислорода проводили оксиметром WTW Oxi 197і с датчиком DurOx 325 с длиной кабеля 100 м. Значения $\mathrm{pH}$ и удельной электрической проводимости (УЭП) устанавливали также соответствующими приборами производства WTW - pHметр 3110 с электродом SenTix 41 и Cond 3110 с ячейкой TetraCon 325. Для определения растворенного органического углерода (РОУ), растворенного неорганического углерода (РНУ), натрия, магния, кальция, хлоридов и сульфатов пробу воды фильтровали через одноразовые шприцевые насадки с PES мембраной Millipore или Sartorius с диаметром пор 0.45 мкм сразу после подъема батометра. Воду для определения сероводорода отбирали в стеклянную посуду, в которую предварительно добавляли раствор ацетата цинка.

Натрий, магний, кальций были определены без концентрирования на ИСП-МС Agilent 8000. Анализ на хлориды и сульфаты осуществляли методом ВЭЖХ. Определение концентраций растворенного органического углерода проводили методом каталитического сжигания на платиновом катализаторе при $800{ }^{\circ} \mathrm{C}$ с инфракрасным детектором $\mathrm{CO}_{2}$ Shimadzu TOC 6000 (погрешность измерений $\pm 2 \%$, предел обнаружения 0.1 мг/л). Щелочность, которая определялась на автоматическом титраторе SCHOTT TA 10plus, далее была пересчитана на неорганический углерод с учетом параметров температуры воды и $\mathrm{pH}$ in situ с использованием константы диссоциации угольной кислоты (Shirokova et al., 2010; Pokrovsky et al., 2010, 2012; Chupakov et al., 2017). Определение растворенного сероводорода и биогенных элементов (фосфор, азот, кремний) осуществляли стандартными фотометрическими методами (РД 52.24.450-2010; ПНД Ф 14.1:2.4-95; Руководство..., 2003).

Определение численности жизнеспособных клеток сульфатредуцирующих бактерий (СРБ) проводили методом десятикратных разведений на минеральной среде Постгейта с лактатом и водородом в качестве донора электронов (Postgate, 1984). 
Статистическая обработка данных

Для рассмотрения вертикального распределения средних значений признака с глубиной нами было проведено осреднение данных в слоях по 5 м. Выборки для каждого признака были проверены на нормальность как с помощью построения гистограмм, так и с применением критерия Шапиро-Уилка $(\mathrm{W}-\mathrm{Tec}, \mathrm{p}=0.05)$. Данный критерий является наиболее применимым для выборок малого объема. Анализ данных показал, что более 40 \% выборок не подчиняются нормальному закону распределения. Поэтому данная работа рассматривается в терминах непараметрической статистики. В качестве критерия среднего нами была выбрана медиана, а в качестве меры неоднородности выборки - значения первого и третьего квартилей.

\section{Результаты и обсуждение}

Температура, кислород, рН, УЭП

Термический режим озер обусловлен приходом и расходом тепла во времени и распределением его в водной массе. Перенос тепла в глубины озера, а следовательно, и термический режим связаны с двумя видами перемешивания вод: конвективным - вертикальным обменом частиц воды, связанным с разностью плотностей этих частиц, и фрикционным (турбулентным), возникающим в результате движения водных масс, вызванного каким-либо динамическим фактором (например, ветер) (Богословский, 1960). Термический режим озера Светлое, в целом, соответствует озерам умеренной зоны. Температура поверхности выше $4{ }^{\circ} \mathrm{C}$ летом и ниже зимой (Хатчинсон, 1969).

В озере Светлое изменения температуры воды были зафиксированы лишь до 25 м, более глубинные горизонты имеют постоянную температуру $3.6 \pm 0.1{ }^{\circ} \mathrm{C}$. Температурные флуктуации в слое 0-25 м в периоды летней и зимней межени демонстрируют классические картины прямой и обратной стратификации. Отсутствие перемешивания обуславливает наличие постоянной анаэробной зоны, начиная с глубины 20 м. В слое 20-25 м происходит резкое увеличение значений УЭП. Характерные значения $\mathrm{pH}$ лежат в интервале $6.80-7.90$ с тенденцией уменьшения значений к придонным горизонтам. Медианные значения концентрации кислорода, значений электропроводности и $\mathrm{pH}$ приведены в табл. 1.

По изменению данных характеристик в озере Светлое можно выделить типичные структуры меромиктического водоема:

1) миксолимнион - слой, подверженный конвективному перемешиванию, мощность от 0 до 20 м, аэробные условия;

2) хемоклин - переходный слой градиента характеристик водной толщи, мощность от 20 до 25 м, где уже отмечаются анаэробные условия, резкое увеличение величины электропроводности (УЭП) и появление в воде растворенного сероводорода;

3) монимолимнион - слой мощностью от 25 м до дна, где сохраняются достигнутые значения электропроводности, происходит накопление биогенных элементов, железа, марганца и сероводорода. В анаэробной зоне ведущая роль в составе общего растворенного железа принадлежит двухвалентной форме (94.2 \%). Количественно железо (в среднем 7 мг/л) и марганец (в среднем 3 мг/л) доминируют в слоях монимолимниона над сероводородом, аммонием и фосфатами (Чупаков и др., 2013).

Кальций, магний, натрий, РОУ, РНУ, хлориды, сульфатьл

Установлено, что в озере Светлое преобладают гидрокарбонат-анион и кальций, что позволяет, используя классификацию природных вод по химическому составу О.А. Алеки- 
Таблица 1. Медианные значения гидрохимических характеристик, осредненные послойно с интервалом в 5 м, за период с 2009-2012 гг.; 25 и 75 \% - значения первого и третьего квартилей (Chupakov et al., 2017)

Table 1. Median values of hydrochemical characteristics layer averaged at intervals of 5 meters for the period 2009-2012; 25 and $75 \%$ - the value of the first and the third quartiles (Chupakov et al., 2017)

\begin{tabular}{|c|c|c|c|c|c|c|c|c|}
\hline $\begin{array}{c}\text { Интервал } \\
\text { глубины, м }\end{array}$ & $0-5$ м & $5-10$ м & $10-15$ м & $15-20$ м & $20-25$ м & $25-30$ м & $30-35$ м & 35 м-дно \\
\hline $\mathbf{O}_{2}, \mathbf{м г / л}$ & $\mathbf{1 1 . 2}$ & $\mathbf{1 1 . 5}$ & $\mathbf{9 . 8}$ & $\mathbf{2 . 7}$ & $\mathbf{0}$ & $\mathbf{0}$ & $\mathbf{0}$ & $\mathbf{0}$ \\
\hline $25 \%$ & 10.1 & 10.3 & 7.2 & 1.0 & 0 & 0 & 0 & 0 \\
\hline $75 \%$ & 12.4 & 12.7 & 11.2 & 5.6 & 0.3 & 0 & 0 & 0 \\
\hline $\mathbf{p H}$ & $\mathbf{7 . 6 9}$ & $\mathbf{7 . 7 0}$ & $\mathbf{7 . 6 2}$ & $\mathbf{7 . 4 0}$ & $\mathbf{7 . 3 8}$ & $\mathbf{7 . 3 0}$ & $\mathbf{7 . 1 3}$ & $\mathbf{7 . 1 7}$ \\
\hline $25 \%$ & 7.30 & 7.42 & 7.27 & 7.00 & 7.04 & 6.94 & 6.80 & 6.92 \\
\hline $75 \%$ & 7.88 & 7.92 & 7.78 & 7.57 & 7.53 & 7.41 & 7.40 & 7.32 \\
\hline УЭП, мкСм/см & $\mathbf{2 1 7}$ & $\mathbf{2 1 7}$ & $\mathbf{2 2 7}$ & $\mathbf{2 3 2}$ & $\mathbf{2 9 3}$ & $\mathbf{3 4 0}$ & $\mathbf{3 4 5}$ & $\mathbf{3 5 0}$ \\
\hline $25 \%$ & 201 & 206 & 219 & 223 & 268 & 318 & 336 & 337 \\
\hline $75 \%$ & 227 & 228 & 245 & 250 & 315 & 361 & 378 & 372 \\
\hline
\end{tabular}

на, отнести воды озера к гидрокарбонатным кальциевой группы І-го типа. Их концентрации, как и УЭП, демонстрируют стратифицированный характер распределения, достигая максимальных значений в монимолимнионе, которые почти в два раза превышают характерные для миксолимниона (рис. $2 a$, г). Концентрации магния, натрия и хлорида существенно не изменяются с глубиной (рис. 2б, $6, \quad e)$, а содержание сульфата уменьшается (рис. 22). Резкая убыль концентрации $\mathrm{SO}_{4}^{2-}$ при незначительном изменении концентрации хлорида свидетельствует о протекании процесса сульфатредукции.

Озеро Светлое отличается малыми значениями концентрации РОУ. Вертикальная структура распределения РОУ имеет тенденцию к увеличению концентраций от поверхности к придонным горизонтам. Среднегодовые концентрации РОУ составляют 1.49 мг/л для миксолимниона и 2.23 мг/л для монимолимниона. Максимальное значение было зафиксировано в придонных горизонтах и равнялось 4.29 мг/л. Данные концентрации РОУ близки к величинам, характерным для вод мирового океана.

\section{Биогенные элементы}

Проведенные исследования показали невысокое содержание растворенных фосфатов в миксолимнионе озера Светлое, медианное значение концентрции 7.13 мкгР/л. Во все сезоны наблюдений прослеживалось увеличение содержания фосфатов на глубинах, соответствующих хемоклину озера. Концентрации фосфатов в анаэробной зоне достигали значений 1748 мкгР/л.

В динамике распределения растворенного аммонийного азота наблюдается возрастание его концентрации с увеличением глубины во все сезоны и резкий скачок концентрации на глубине 20-25 м. При этом медианное значение концентрации $\mathrm{N}_{-} \mathrm{NH}_{4}{ }^{+}$в монимолимнионе озера Светлое достигает значений 2266 мкгN/л. Независимо от сезона содержание аммонийного азота в миксолимнионе невелико, в среднем 10.13 мкгN/л.

Суммарное содержание нитритного и нитратного азота показывает небольшое увеличение концентраций с ростом глубины. Средние концентрации в миксолимнионе составляют около 100 мкгN/л, а в монимолимнионе - 140 мкгN/л. В целом, эти показатели 

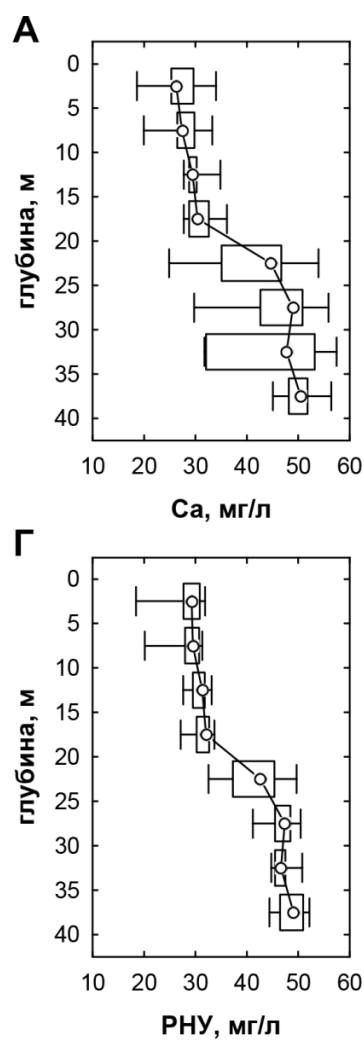

- - Медиана
Б

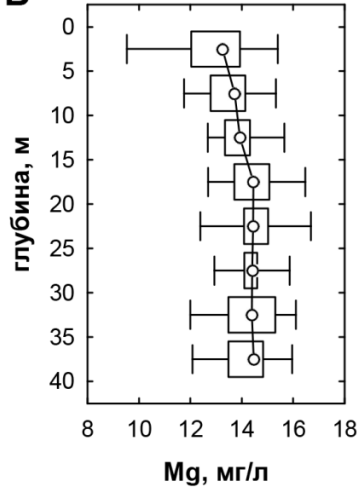

म

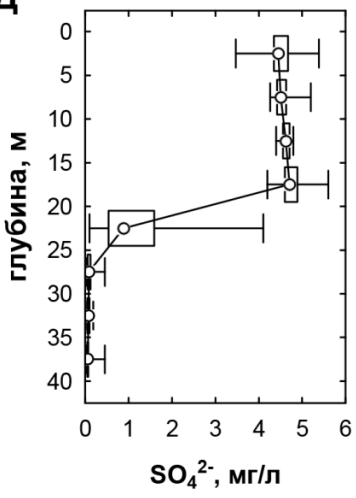

$25 \%-75 \%$

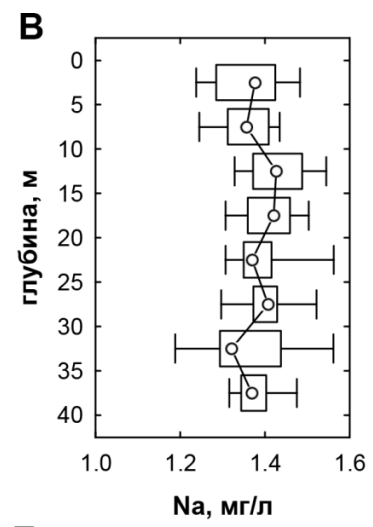

E

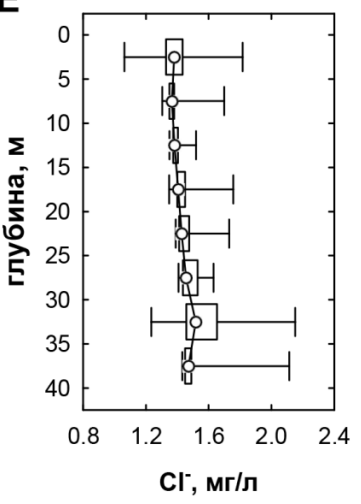

Рис. 2. Медианные значения концентраций $\mathrm{Ca}^{2+}(\mathrm{A}), \mathrm{Mg}^{2+}\left(\right.$ Б), $\mathrm{Na}^{+}(\mathrm{B}), \mathrm{PHУ}(Г), \mathrm{SO}_{4}^{2-}$ (Д), $\mathrm{Cl}^{-}$(Е) за 20092012 гг.

Fig. 2. Median values of $\mathrm{Ca}^{2+}(\mathrm{A}), \mathrm{Mg}^{2+}\left(\right.$ () $, \mathrm{Na}^{+}(\mathrm{B}), \mathrm{DIC}(\Gamma), \mathrm{SO}_{4}{ }^{2-}$ (Д), $\mathrm{Cl}^{-}(\mathrm{E})$ concentrations for 2009-2012

проявили довольно высокую сезонную изменчивость, особенно в поверхностном горизонте $0-5 \mathrm{~m}$.

В распределении содержания общего азота наблюдается резкое его увеличение в зоне хемоклина. При средних значениях в миксолимнионе 192.4 мкгN/л содержание общего азота достигает значений 3603 мкгN/л в придонных горизонтах. Наблюдается достаточно высокое содержание $\mathrm{N}_{\text {opr }}$, которое варьирует в миксолимнионе в пределах 17-70 \%, а в монимолимнионе - 32-95 \% от $\mathrm{N}_{\text {общ }}$.

Содержание растворенных соединений кремния, как и других биогенных элементов, увеличивается с глубиной. При концентраци- ях в миксолимнионе 2584 мкг/л в монимолимнионе они возрастают на порядок и достигают 13181 мкг/л.

\section{Сероводород, сульфаты и}

сульфатредуцируюшие бактерии

Выявлено постоянное присутствие в воде озера растворенного сероводорода. В табл. 2 приведены усредненные данные по содержанию сероводорода по годам и за весь период исследований. В кислородных водах он обнаруживается эпизодически в микроколичествах - его содержание не превышало в подавляющем большинстве случаев 0.405.33 мкг/л, составляя в среднем 2.42 мкг/л. 
Таблица 2. Медианные значения концентрации сероводорода (мкг/л), усредненные послойно с интервалом в 5 м; 25 и $75 \%$ - значения первого и третьего квартилей

Table 2. Median values of hydrogen sulfide concentration ( $\mu \mathrm{g} / \mathrm{l})$ layer averaged at intervals of $5 \mathrm{~m} ; 25$ and $75 \%-$ the values of the first and the third quartiles

\begin{tabular}{|c|c|c|c|c|c|c|c|}
\hline $\begin{array}{c}\text { Интервал } \\
\text { глубины }\end{array}$ & 2010 г. & 2011 г. & 2012 г. & 2013 г. & 2014 г. & 2015 г. & $\begin{array}{l}\text { За весь } \\
\text { период }\end{array}$ \\
\hline $0-5$ м & 2.20 & 0.91 & 3.90 & 2.21 & 7.86 & 0.12 & 1.75 \\
\hline $25 \%$ & 0.56 & 0.12 & 1.76 & 1.27 & 6.78 & н.д. & 0.40 \\
\hline $75 \%$ & 4.42 & 1.66 & 4.84 & 5.46 & 10.01 & н.д. & 4.97 \\
\hline $5-10$ м & 2.59 & 1.15 & 3.81 & 2.28 & 8.01 & \multirow{3}{*}{ н.д. } & 2.52 \\
\hline $25 \%$ & 1.13 & 0.33 & 2.35 & 1.21 & 5.09 & & 1.15 \\
\hline $75 \%$ & 4.73 & 1.87 & 5.25 & 3.61 & 10.93 & & 5.01 \\
\hline $10-15$ м & 2.23 & 1.56 & 3.33 & 2.08 & 9.21 & \multirow{3}{*}{ н.д. } & 2.81 \\
\hline $25 \%$ & 1.39 & 1.14 & 1.81 & 1.72 & 5.09 & & 1.30 \\
\hline $75 \%$ & 5.47 & 2.48 & 3.71 & 3.35 & 12.98 & & 4.93 \\
\hline $15-20$ м & 2.22 & 1.85 & 3.20 & 3.34 & 24.25 & 1.76 & 2.31 \\
\hline $25 \%$ & 1.13 & 0.64 & 1.97 & 1.20 & 2.17 & н.д. & 1.37 \\
\hline $75 \%$ & 6.08 & 2.89 & 4.53 & 5.81 & 9.55 & н.д. & 5.33 \\
\hline $20-25$ м & 12.42 & 10.16 & 27.78 & 7.59 & 40.10 & 41.31 & 15.43 \\
\hline $25 \%$ & 5.47 & 4.38 & 7.71 & 5.76 & 11.96 & н.д. & 5.45 \\
\hline $75 \%$ & 16.98 & 12.83 & 43.67 & 11.80 & 66.51 & н.д. & 19.64 \\
\hline $25-30$ м & 25.75 & 18.29 & 14.45 & 13.71 & 20.04 & 34.65 & 18.72 \\
\hline $25 \%$ & 19.34 & 11.44 & 8.78 & 7.61 & 14.88 & н.д. & 11.39 \\
\hline $75 \%$ & 28.02 & 24.66 & 20.20 & 17.54 & 21.64 & н.д. & 26.15 \\
\hline $30-35$ м & 30.20 & 30.96 & 30.57 & 31.40 & 38.10 & 32.91 & 30.59 \\
\hline $25 \%$ & 26.02 & 29.48 & 27.94 & 27.89 & 36.91 & н.д. & 28.25 \\
\hline $75 \%$ & 31.23 & 31.83 & 31.78 & 32.50 & 41.62 & н.д. & 32.65 \\
\hline 35 м-дно & 28.51 & 33.47 & 35.04 & 28.91 & 43.77 & \multirow{3}{*}{ н.Д. } & 34.39 \\
\hline $25 \%$ & 28.11 & 30.35 & 32.70 & 28.81 & 37.78 & & 29.93 \\
\hline $75 \%$ & 32.18 & 33.63 & 37.62 & 36.08 & 41.77 & & 36.68 \\
\hline
\end{tabular}

Зона хемоклина характеризуется наличием максимумов в распределении сероводорода - именно здесь отмечены его наиболее высокие концентрации - 19-26 мкг/л (максимально 132.5 мкг/л). Наименее отчетливо этот максимум был выражен летом 2013 г., наиболее ярко - практически весь 2012 г. Хотя в настоящее время исследования проводятся эпизодически, полученные в зимний период 2014-2016 гг. максимальные концентрации сероводорода в зоне хемоклина составляют 70-100 мкг/л, т.е. близки к данным 2012 г. Следует отметить, что отсутствие данного максимума в 2010 г. является не гидрохимической аномалией, а следствием всего лишь низкой дискретности отбора в этот период. Как выяс- нилось при дальнейших исследованиях, при отборе проб пятилитровым горизонтальным батометром можно пропустить многие интересные и важные явления на хемоклине при шаге отбора более 0.5 м. Как видно из данных рис. 3 , трудно выделить какие-либо отчетливо выраженные сезонные закономерности в распределении сероводорода в зоне хемоклина.

Наиболее однородное распределение сероводорода отмечено в анаэробной зоне озера Светлое. Здесь во все периоды исследования его концентрации преимущественно изменялись в интервале от 11.4 до 36.7 мкг/л, составляя в среднем 30.9 мкг/л.

Содержание сульфатов в кислородных водах озера сравнительно невелико (рис. 2d), 

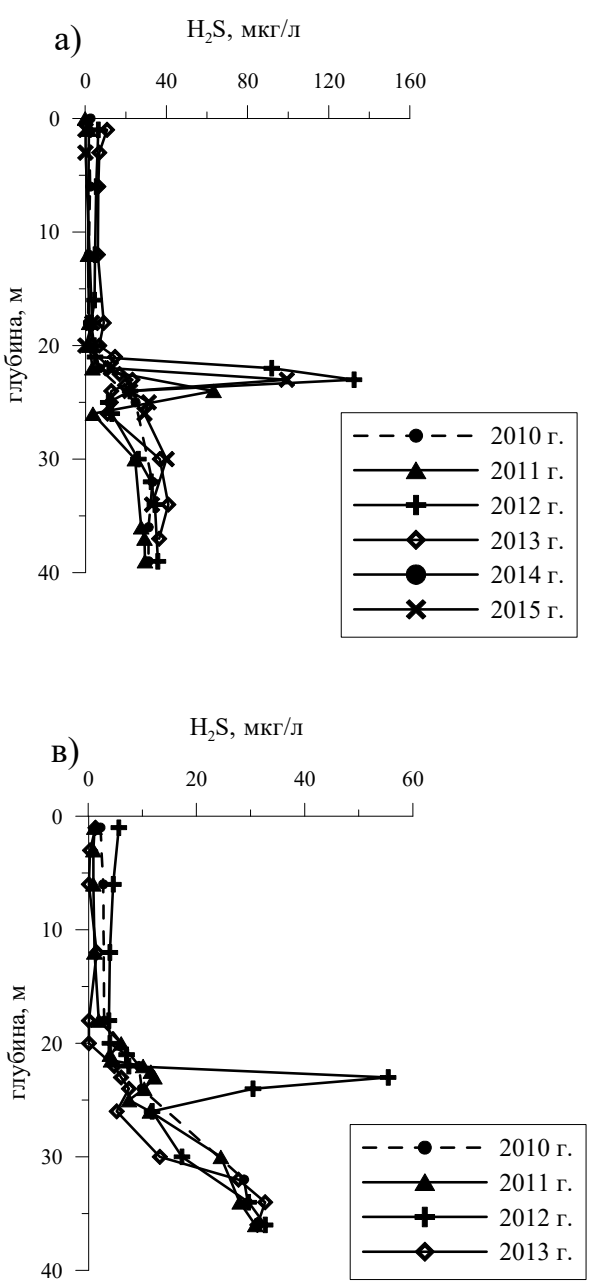

б) $\mathrm{H}_{2} \mathrm{~S}$, мкг/л

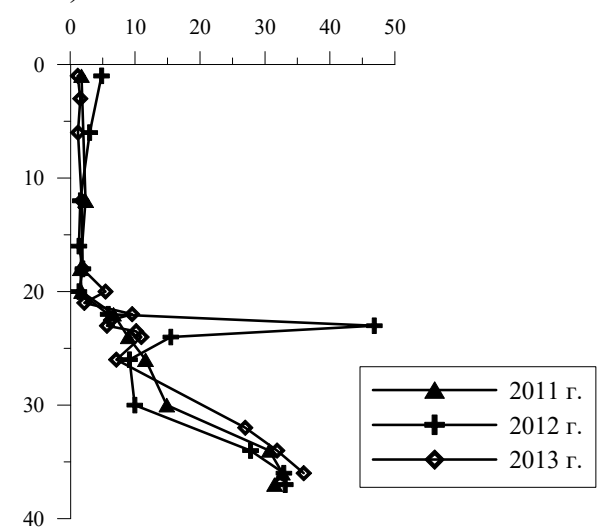

г) $\quad \mathrm{H}_{2} \mathrm{~S}$, мкг/л

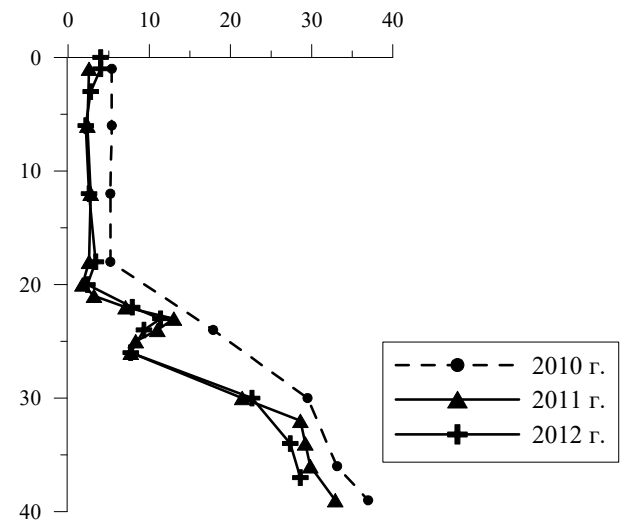

Рис. 3. Вертикальное распределение растворенного сероводорода в озере Светлое в разные климатические сезоны: а - зима; б - весна; в - лето и г - осень

Fig. 3. Vertical profiles of dissolved hydrogen sulphide in Lake Svetloye in different seasons: a - winter; $\sigma$ - spring; в - summer and $\Gamma$ - autumn

в среднем 4.6 мг/л (от 3.5 до 5.6 мг/л); в зоне хемоклина оно снижается - до 1 мг/л (от 0.1 до $4.11 \mathrm{мг/л),} \mathrm{а} \mathrm{в} \mathrm{анаэробной} \mathrm{зоне} \mathrm{равняется} \mathrm{всего}$ 0.1 мг/л (от 0.1 до 0.5 мг/л), что обусловлено, скорее всего, потреблением их сульфатредуцирующими бактериями в процессе генерации сероводорода. Как показано на рис. 4, в зимний и летний периоды в зоне хемоклина (21-24 м) над максимумом сероводорода фиксировался отчетливо выраженный максимум сульфатов. Увеличение концентрации сульфата связано с окислением сероводорода как хи- мическимпутемпри контакте с кислородными водами, так и при участии микроорганизмов. Воды хемоклина в течение всего периода наблюдений были окрашены в розоватый цвет, который связан с наличием достаточно высокой численности фикоэритринсодержащих цианобактерий Synechococcus sp. (Забелина и др., 2014; Savvichev et al., 2017).

Численность СРБ в водной толще за время наблюдений колебалась от 10 до $10^{6}$ кл/мл. Максимальное их содержание консолидировано с максимумом сероводорода и выявлено 

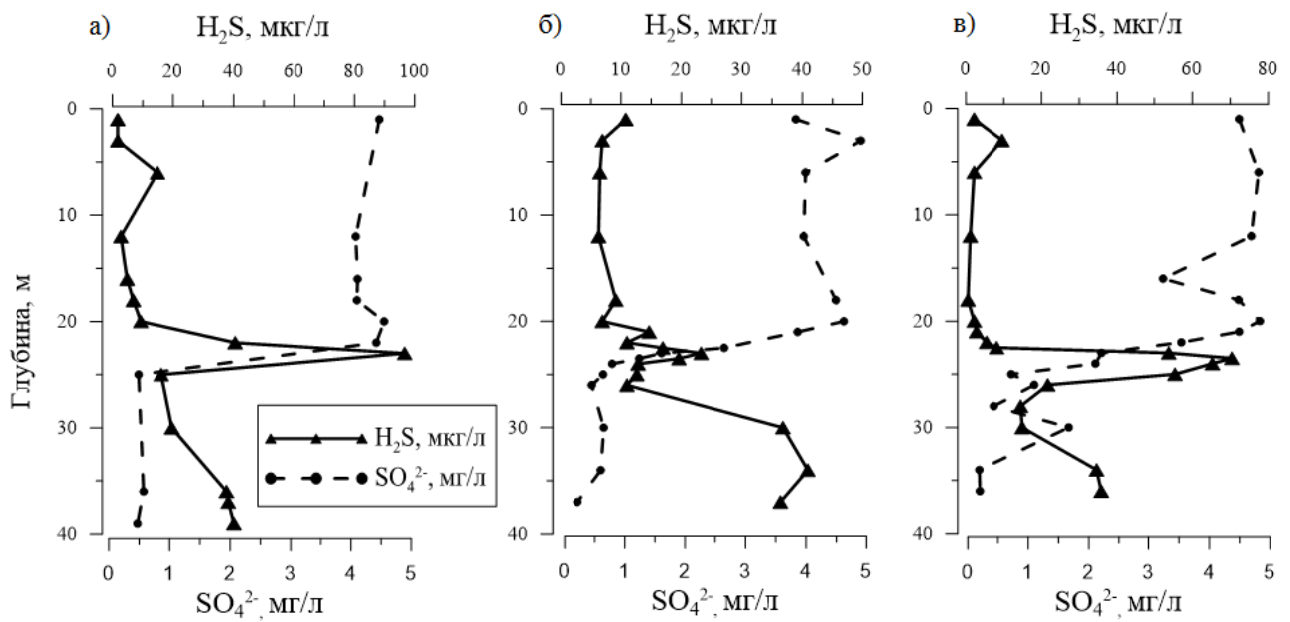

Рис. 4. Вертикальное распределение сероводорода и сульфатов озера Светлое в зимний период 2012 (a), 2013 (б) и 2014 (в) гг.

Fig. 4. Vertical profiles of hydrogen sulphide and sulphates in Lake Svetloye in winter 2012 (a), 2013 (б), and 2014 (в)

в зоне хемоклина (23-24 м). В разные сезоны численность СРБ в зоне хемоклина варьировала от $10^{4}$ кл/мл в июле 2011 г. до $6 \cdot 10^{5}$ в марте 2011 г. и $10^{6}$ кл/мл в апреле 2014 г. Далее с увеличением глубины численность СРБ снижается до нескольких сотен кл/мл в придонном горизонте. Максимальная интенсивность сульфатредукции также была обнаружена в зоне хемоклина (Savvichev et al., 2017), с увеличением глубины интенсивность процесса уменьшалась.

В июле 2011 г. посев проб воды производился на среды с лактатом и водородом в качестве донора электронов. В составе СРБ в зоне хемоклина преобладали $\mathrm{H}_{2}$-утилизирующие, в монимолимнионе соотношение СРБ, утилизирующих лактат и $\mathrm{H}_{2}$ было одинаковым.

\section{Заключение}

По результатам изучения вертикального распределения температуры, кислорода, pH и электропроводности в воде пресноводного озера Светлое установлено наличие устойчивой стратификации с выделением характерных для структуры меромиктических во- доемов слоев. В переходном слое (хемоклин) начало анаэробной зоны сопровождается резким увеличением величины электропроводности и появлением в воде растворенного сероводорода.

Ниже хемоклина в анаэробных зараженных сероводородом водах монимолимниона происходит накопление биогенных элементов (азота, фосфора, кремния), обусловленное, с одной стороны, отсутствием потребляющих их организмов и анаэробной деструкцией седиментационного материала, а с другой - потоком этих элементов из донных отложений. Вариации концентраций сероводорода в монимолимнионе невелики, а его среднее содержание составляет 27 мкг/л. Здесь же отмечено заметное снижение содержания растворенного сульфата, обусловленное, скорее всего, его потреблением сульфатредуцирующими бактериями при генерации сероводорода.

Численность сульфатредуцирующих бактерий в водной толще за все время наблюдений колебалась в интервале от 10 до $10^{6}$ кл/мл, с максимумом содержания в зоне хемоклина, где также отмечены максималь- 
ные количества сероводорода (до 130 мкг/л). В составе СРБ в зоне хемоклина преобладали $\mathrm{H}_{2}$-утилизирующие, в монимолимнионе соотношение СРБ, утилизирующих лактат и $\mathrm{H}_{2}$ было одинаковым.

Постоянное присутствие сероводорода в монимолимнионе меромиктического пресноводного озера Светлое в концентрациях, значительно (в десятки раз) меньших содержания растворенного двухвалентного железа, позволяет рассматривать это озеро как современный аналог богатых железом и бедных сульфидами раннепротерозойских (древнее 2.5-2.4 млрд. лет) водоемов. Выявленная специфика физико-химических параметров водной толщи делает возможным проведение уникальных исследований по изучению процессов анаэробной минерализации органического вещества (сульфатредукции и метаногенеза), аноксигенного фотосинтеза, трансформации вещества на окислительновосстановительных геохимических барьерах.

Работа выполнена при финансовой поддержке ФАНО России в рамках тем ФНИР № 0409-2015-0138 № zос. регистрации - АAAA-A18-118012390167-1 и №̣ 0409-2015-0140 № zoc. рег. АAАA-A18-118012390200-5, Проекта УрО РАН № 15-2-5-36, гранта РФФИ № 16-35-00330мол_a.

\section{Список литературы}

Богословский Б.Б. (1960) Озероведение. М., МГУ, 334 с. [Bogoslovskiy В.В. (1960) Limnology. Moscow, Moscow State University, 334 p. (in Russian)]

Забелина С.А., Компанцева Е.И., Чупаков А.В., Ершова А.А. (2014) Сезонная динамика фотосинтетических пигментов в пресноводном меромиктическом озере. Биодиагностика состояния природных и природно-техногенных систем: Материалы ХІІ Всероссийской научно-практической конференции с международным участием. Т. 1. Киров, Веси, с. 119123 [Zabelina S.A., Kompantseva E.I., Chupakov A.V., Ershova A.A. (2014) Seasonal dynamics of photosynthetic pigments in the fresh-water meromictic lake. Biodiagnostics of a condition of natural and natural - technogenic systems: Materials of the XII All-Russian scientific and practical conference with the international participation. Vol. 1. Kirov, Vesi, p. 119-123 (in Russian)]

Кокрятская Н.М., Забелина С.А., Титова К.В., Чупаков А.В., Воронцова О.Н., Филина К.В. (2011) Биогеохимические исследования системы стратифицированных озер реки Светлая (водосборный бассейн Белого моря). Геология морей и океанов: материаль ХVIII Межд. научной конф. (Школь) по морской геологии. Т. 4. Москва, ГЕОС, с. 58-62 [Kokryatskaya N.M., Zabelina S.A., Titova K.V., Chupakov A.V., Vorontsova O.N., Filina K.V. (2011) Biogeochemical study of the system of stratified lakes in river Svetlaya (White Sea drainage basin). Geology of seas and oceans: materials XVIII International Conference (School) on marine geology. Vol. 4. Moscow, GEOS, p. 58-62 (in Russian)]

Малов А.И. (2003) Подземные воды Юго-Восточного Беломорья: формирование, роль в геологических проиессах. Екатеринбург, УрО РАН, 234 с. [Malov A.I. (2003) Groundwater of Southeastern Belomorie: formation and role in geological processes. Ekaterinburg, Ural Department of Russian Academy of Sciences, 234 p. (in Russian)]

ПНД Ф 14.1:2.4-95 (1995) Количественный химический анализ вод. Методика выполнения измерений массовой концентрации нитрат-ионов в природных и сточных водах фотоме-

$$
-157-
$$


трическим методом с салициловой кислотой. М., Изд-во стандартов, 20 с. [Nature protection Normative Document of federal level 14.1:2.4-95 (1995) Quantitative chemical analysis of water. Methods of measurement of the mass concentration of nitrate ions in natural and waste waters by photometric method with salicylic acid. Moscow, Publishing House of Standards, 20 p. (in Russian)]

РД 52.24.450-2010 (2010) Массовая концентрачия сероводорода и сульфидов в водах. Методика выполнения измерений фотометрическим методом с N,N'-диметил-n-фенилендиамином. Росгидромет, 50 с. [Guidance Document 52.24.450-2010 (2010) Mass concentration of hydrogen sulphide and sulfides in waters. Method for performing measurements by photometric method with $N, N$ '-dimethyl-n-phenylenediamine. Roshydromet, 50 p. (in Russian)]

Руководство по химическому анализу морских и пресных вод при экологическом мониторинге рыбохозяйственных водоемов и перспективных для промысла районов Мирового океа$н а$ (2003) М., ВНИРО, 202 с. [Guidance on the chemical analysis of salt and fresh waters at the ecological monitoring of fisheries reservoirs and perspective for trade districts of the World ocean (2003) Moscow, VNIRO, 202 p. (in Russian)]

Хатчинсон Д. (1969) Лимнология. Географические, физические и химические характеристики озер. М., Прогресс, 591 с. [Hutchinson D. (1969) Limnology. Geographical, physical and chemical characteristics of lakes. Moscow, Progress, 591 p. (in Russian)]

Чупаков А.В., Покровский О.С., Широкова Л.С., Воробьева Т.Я., Забелина С.А., Кокрятская Н.М., Морева О.Ю., Ершова А.А., Шорина Н.В., Климов С.И. (2013) Гидрохимические особенности пресноводного меромиктического оз. Светлое (Архангельская область). Вестник Северного (Арктического) федерального университета. Серия "Естественные нау$\kappa u ”, ~ 1: ~ 20-31$ [Chupakov A.V., Pokrovsky O.S., Shirokova L.S., Vorobyyova T.Ya., Zabelina S.A., Kokryatskaya N.M., Moreva O.Yu., Ershova A.A., Shorina N.V., Klimov S.I. (2013) Hydrochemical characteristics of meromictic freshwater lake Svetloe (Arkhangelsk region). Vestnik of Northern (Arctic) Federal University. Series Natural Sciences [Vestnik Severnogo (Arkticheskogo) federalnogo universiteta. Seriya “Estestvennye nauki”], 1: 20-31 (in Russian)]

Chupakov A.V., Chupakova A.A., Moreva O.Yu., Shirokova L.S., Zabelina S.A., Vorobieva T.Y., Klimov S.I., Brovko O.S., Pokrovsky O.S. (2017) Allochthonous and autochthonous carbon in deep, organic-rich and organic-poor lakes of the Europian Russian subarctic. Boreal Environment Research, 22: $213-230$

Pokrovsky O.S., Shirokova L.S., Zabelina S.A., Vorobiova T.Ya., Moreva O.Yu., Chupakov A.V., Shorina N.V., Kokryatskaya N.M., Andry S., Viers J., Zoutien C., Freydier R. (2012) Size fractionation of trace elements in a seasonally stratified boreal lake: control of organic matter and iron colloids. Aquatic Geochemystry, 18(2): 115-139. DOI: 10.1007/s10498-011-9154-z

Pokrovsky O.S., Viers J., Shirokova L.S., Shevchenko V.P., Filipov A.C., Dupre B. (2010) Dissolved, suspended, and colloidal fluxes of organic carbon, major and trace elements in the Severnaya Dvina River and its tributary. Chemial Geology, 273: 136-149. DOI: 10.1016/j.chemgeo.2010.02.018

Postgate J.R. (1984) The sulphate bacteria. Cambridge University Press, 208 p.

Savvichev A., Kokryatskaya N., Zabelina S., Rusanov I., Zakharova E., Veslopolova E., Lunina O., Patutina E., Bumazhkin B., Gruzdev D., Sigalevich P., Pimenov N., Kuznetsov B., Gorlenko V. (2017) Microbial processes of the carbon and sulfur cycles in an ice-covered, iron-rich meromictic lake 
Svetloe (Arkhangelsk region, Russia). Environmental Microbiology, 19(2): 659-672. DOI: 10.1111/14622920.13591

Shirokova L.S., Pokrovsky O.S., Viers J., Klimov S.I., Moreva O.Yu., Zabelina S.A., Vorobieva T.Ya., Dupre B. (2010) Diurnal variations of trace metals and heterotrophic bacterioplankton concentration in a small boreal lake of the White Sea basin. Annales de Limnologie, 46: 67-75. DOI: 10.1051/limn/2010011 